\title{
The Current Situation and the Strategy for the Development of Logistics Park in Chinese Bonded Area
}

\author{
KUANG $\mathrm{Mo}^{1}, \mathrm{CHEN}$ Ping $^{2}$, TAN Mingjun ${ }^{3}$ \\ 1.KUANG Mo, Business School of Guangzhou University, Guangzhou510006,PRC. \\ kuangmo-169@263.net \\ 2.CHEN Ping, Foshan Polytechnic, Foshan528137, PRC.chenping_802 \\ <18202077989@163.com
}

3.TAN Mingjun, Foshan Polytechnic, Foshan528137, PRC. mingjunt@sina.cn

Keywords: Regional Economies, Logistics Bonded Area, Countermeasure

\begin{abstract}
It is since that Chinese Bonded Area was set in April 1990, Chinese Logistics Park has been shaped gradually. It is developing by reference to varied Free-trade Areas in different countries, together with the objective requirement of Chinese Reform and Opening-up and Chinese Economic Development. The article analyzes the current situation and the strategy for the Development of Logistics Park in Chinese Bonded Area. It suggests the way to deal with the situation that as below. (1) Improving International Freeway with Multimodal International Transport System; (2) Improving the logistics by building the international logistics information system, by the Information Globalizing;(3) Improving the international logistics network by cooperating the shipping consortium; (4) Encouraging the development of the third-party and the forth-party logistics; (5) Green logistics management in full operation; (6) Make more policy slope to encourage the logistics; (7) Improving customs clearance system to adapt the requirement of international logistics development.
\end{abstract}

\section{Introduction}

Bonded area (the low-tax, tariff-free zone or tax-protected zone) is also known as bonded warehouse area, which refers to the area established at the harbor, airport or other places under the approval of customhouse of sovereign state for the purpose of long-term continuous storage of foreign cargoes without undergoing import and export formalities. It is the area as established by or registered under the approval of customhouse of one certain state for storage of commodities for relatively long period under the supervision and control of the customhouse. It is an economic area under the special supervision and control of customhouse as established by the State Council. It is also the economic area of enjoying maximum openness and freedom in our country. Definition of bonded area in narrow sense is stated as follows: A special area as established by or registered under the approval of customhouse; imported commodities can be stored in the bonded warehouse of bonded area for the time being under the supervision of customhouse without payment of import duty; such commodities will be exempted from export duty if they are exported again; however, it is necessary to pay import duty for any imported commodity for sale in domestic market. Definition of bonded area in broad sense is stated as follows: Bonded areas in some countries are provided with similar functions of free port and export processing zone; Bonded areas in China are also provided with similar functions of the later for the purpose of invitation of foreign investment, introduction of advanced technologies and governing approaches, provision of more job opportunities and promotion of export trade. In other words, this aims to facilitate allocation of bonded warehouses, transit of investment and processing or research and development for commodities of foreign merchants and domestic enterprises. Bonded area is a new economic zone as established under the approval of State Council following special economic zone, economic and technical development zone and national hi-tech industrial development zone. As operated as per international custom, bonded area enjoys more flexible and favorable policies as compared with other opened regions. Bonded area is provided with three functions, namely bonded warehousing, export processing and 
transit trade. Furthermore, bonded area is also provided with such functions as import and export processing, international trade and exhibition of commodities in bonded storage. It is in the operation mode of "inside the territory and outside the customs", which enjoys the policy of "certification-free, tariff-free and bonding”. It is one of economic zones enjoying the highest openness, the most convenient operation mechanism and the most favorable policies in China. Bonded area can promote transit trade, and increase revenues from relevant expenses. Cargoes as delivered to the bonded area are available for storage, repackage, classification, mixing, and exhibition as well as processing and manufacturing under the supervision of customhouse. Imported commodities in the bonded area are available for free export at relatively low cost after payment of storage charges other than import duty. However, customs duties are to be collected for the entry of imported commodities. Deadline as stipulated by bonded areas in different countries is varied. Any customhouse has the right to proceed with auction for any cargo without relevant formalities. The balance after deduction of relevant expenses is to be returned to the owner.

"Bonded area" normally refers to an open area as established in or out of the territory of one nation, which is similar to foreign export processing zone and free trade zone. Delivery of commodities from non-bonded area to the bonded area will be deemed as export; whereas delivery of commodities from the bonded area to the non-bonded area will be deemed as import. Bonded areas in China are under the fully enclosed and isolated management, which are provided with complete supporting facilities. In the opinion of Jack North: "Bonded areas in China are not free trade zones in a comprehensive sense; for instance, any trading enterprise as invested and registered in the bonded area will not be permitted for registration at the customhouse if it has no export operation right; any trading enterprise will have to face the problem of multilevel agency when purchasing commodities abroad; this may result in increased trading cost on the part of enterprises settled in the bonded area; many enterprises engaged in distribution of foreign trade commodities might be stuck in troubles if they are unable to solve this problem effectively”.

\section{The Logistics Park Development in Abroad Bonded Area}

Livorno Free Port, the first free port in the world was established at Genoa Bay in Italy in 1547. Free economic trade zones in the world have witnessed a development for over 400 years since then. Free economic zone is a special area as divided by one nation or region as per relevant decrees within its territory for the purpose of promoting foreign trade activities under the supervision of customhouse. Tariff policies as implemented in this area are normally different from those in other regions, which aim to attract foreign investment, promote foreign trade, introduce advanced technologies and management experiences from other countries, create more job opportunities, increase exchange earnings and financial revenues. Free port is the initial form of free economic

zone, which is an important port measure as taken by one certain sovereign state for protective tariff. In principle, all imported commodities within the free port are exempted from tariff whether they are for local consumption or transit export, which are also available for free loading, unloading, storage, repackage, transaction, processing and manufacture. However, foreign ships must abide by legal provisions as stipulated by the sovereign state on sanitation, public security and migration. The most famous modern free ports include Hong Kong, China and Singapore. Accompanied by cultural and economic development world wide, a new form of free economic zone, the free trade zone, has been gradually developed in developed regions. Free trade zone as developed on the basis of free port has high universality owing to its early establishment and extensive distribution. All countries (regions) are in a disordered situation on the issue of definition of free trade zone. Even the most authoritative international institutions are unable to give a uniform definition. U.S.A is a representative nation in terms of study of free trade zone. U.S.A is the first nation establishing free trade zone in the world, which comes to the top in the world in terms of the number of free trade zones. In 1990s, U.S.A took the lead in establishing a relatively comprehensive free trade zone system.

There is no essential difference between free port and free trade zone. Free trade is located in the port or one special area in the city; whereas free port normally refers to the port and the city. 
Although management approaches in different countries are varied, common points are still in existence. Firstly, commodities can enter the free trade zone or free port without payment of customs duties and handling of entry formalities. Secondly, commodities are covered by the commodity range as specified by respective nation (region). Thirdly, all commodities entering the free trade zone or free port are available for disassembly, storage, gradation, classification, repair, reproduction, repacking, relabeling, cleaning, destruction and mixing with homemade and imported commodities or re-export, which are free of monitoring and supervision by the customhouse. Fourthly, it is necessary to proceed with customs declaration and payment of import duty if commodities as delivered to the free trade zone or free port are to be transported to other regions. Fifthly, imported commodities are available for repacking within the free trade zone or free port if their practical gross weight exceeds the net weight of cargoes plus the tare as specified by the customhouse. Sixthly, all activities in and out of the zone are not limited. Seventhly, the government will relax financial control in the free trade zone or free port to implement financial liberalization.

Major features of free economic zones in foreign countries are stated as follows: Proactively encourage foreign merchants and enterprises to make investment through implementation of tariff-free policies and other favorable taxation policies by taking the free economic zone as the "zone in the territory and outside the customs". Secondly, simplify supervision and control formalities of customhouse. Thirdly, develop comprehensive functions based on the initial export processing function to further expand functions of free economic zone.

Governments of foreign countries play the following roles in planning of logistics park. Firstly, financial supporter: For instance, Japanese Government is aware of the fact that establishment of large logistics park requires enormous investment and long payoff period. However, it is helpful to improvement of cities as it can bring about significant social benefits. Therefore, interest of loan as granted by the bank to enterprise is also extremely low. In Japan, government would sell the land for construction of logistics parks to development corporations at an extremely low price. Furthermore, such logistics parks are jointly constructed with business enterprises applying bank loan. Secondly, the role of general planner: For instance, Deutsche Bahn and Railway Bureau of Democratic Germany jointly completed “Overall Planning for National Logistics Park” as proposed by German Government in consideration of railway transportation in 1992. As planned, 28 logistics parks were constructed in Germany. In 1995, the planning was revised to increase the number of logistics parks from 28 to 39 in an attempt to form a logistics network.

\section{The Current Situation of Logistics Park in Chinese Bonded Area.}

\subsection{Summary of Development}

Bonded area is a new political tool and economic phenomenon for economic development. As it is new to China, progress in study of bonder area is insignificant. However, with adoption of reform and opening policy and continuous trial of new things, China has become stronger accompanied by accelerated economic development. Scholars in China are aware of the fact the expanded import and export trade in China is beyond the reach of China's economy, which may result in the situation "backfire" at any time. Under such circumstance, the most important issue at present is to change the trading mode so as to better adapt to expanded trade. Development of bonded areas is accompanied by thinking and practice. In June, 1990, the first bonded area in China, Shanghai Waigaoqiao Free Trade Zone located in Pudong New Area, Shanghai was formally established under the approval of State Council. 15 bonded areas have been formally established under approval since 1990, namely Shanghai Waigaoqiao Free Trade Zone located in Pudong New Area, Shanghai, Tianjin Free Trade Zone, Shenzhen Shatoujiao Bonded Area, Shenzhen Futian Bonded Area, Dalian Free Trade Zone, Guangzhou Free Trade Zone, Zhangjiagang Free Trade Zone, Haikou Free Trade Zone, Xiamen Xiangyu Free Trade Zone, Fuzhou Free Trade Zone, Ningbo Free Trade Zone, Qingdao Free Trade Zone, Shantou Free Trade Zone, Shenzhen Yantian Bonded Are and Zhuhai Free Trade Zone. As such major functions as transit trade and bonded warehousing of each bonded area are different, the development degree is also varied. By the end of 2001, 13180 foreign invested enterprises has been registered in bonded areas with total investment over 17 
billion US dollars. Such investment is from over 80 countries and regions in the world. After exploration and practice for years, comprehensive economic strength of China has been improved accompanied by significant increase in import and export trading volume. Furthermore, China also successfully attracted enormous foreign investment. Development of bonded areas and capital globalization has laid down a solid foundation for globalization of China's logistics industry.

A new economic area, bonded area has been established in China under the approval of State Council following establishment of economic development zones, special economic zones and national hi-tech industrial zones. As compared with previously established zones, new economic areas as operated as per international custom enjoy more flexible and favorable policies, which has attracted attentions from enterprises both at home and abroad ever since their establishment. After development and practice for years, each bonded area has focused on development of its unique features into an important economic composition based on the guideline of "good timing, geographical convenience and good human relations". Bonded area is one of special economic zones enjoying highest reform and opening degree, the most convenient operation mechanism and the most favorable policies in China at present. It has successfully attracted more domestic and foreign investment, and promoted development of regional economy. Meanwhile, it has also accumulated precious experiences for globalization. It is applicable to create more attractive conditions for domestic and foreign enterprises through imitation and optimization of the operation mode of free port and free trade zone as widely accepted internationally based on the perfect infrastructures. This aims to enable bonded area to become an important force for the foreign economic development.

China became a formal member of WTO on December 11, 2001. People have put forward other questions on bonded areas: If basic principles of WTO are in conflict with bonded areas? if bonded areas are to be reserved? We can consider two protocols among relevant protocols of WTO: (1) Definite regulations on establishment of tariff alliance and free trade zone in adjacent contracting states for the purpose of regional economic cooperation are specified in Article 24 of General Agreement on Tariffs and Trade; it is widely accepted that such form is favorable for integration of multilateral trade in the world and acceleration of international investment and free trade. (2) Viewing from regulations as specified in General Agreement on Tariffs and Trade, we can see that the two are not in conflict with each other, which are favorable for mutual promotion.

3.2 The Foundation of the Logistics Park in Bonded Area

Bonded area has significantly promoted the development of China's foreign trade and national economy since its establishment in June, 1990. It is mainly manifested in the following aspects: (1) As system for bonded areas in China is stipulated in reference to national conditions and foreign free trade zones (free ports), it can accelerate the import and export turnover in China. It plays an extremely proactive role in promoting opening of China, which is an essential form of economic zone. (2) Establishment of bonded area is an important milestone for economic development in China, which plays a demonstration role in reform of economic system of China. Meanwhile, it can indicate orientation and rules for the development of market economy in the future to a great extent. It is applicable to enable foreign countries to be aware of our determination in the reform of economic system and reform orientation through introduction of well-established systems of foreign countries by taking the bonded area as the "medium". (3) Bonded area is favorable for development of transit trade in one certain nation and improvement of production level in countries with bonded areas. It also plats an important and proactive role in promoting foreign trade and economic development. However, due to such disadvantages as congenital deficiency and post maladjustment to the development of bonded areas in China, economic function of bonded areas are significantly restricted.

\subsection{Existing Questions}

3.3.1 The Legal Questions

Perfect management of any economic zone should be based on relevant laws. However, legal system in China is still to the optimized. As acceptable standards and regulations on the definition, orientation and operation mode of bonded area are unavailable, numerous problems may occur 
during practical operation of bonded area. Among them, the most serious problem is the year-on-year reduction in tariff level in China. Opening and foreign investment invitation has become the focus of development of bonded areas since China became a formal member of WTO in December 11, 2001. Meanwhile, Chinese Government has also enhanced the upgrading of infrastructures and construction input. Nevertheless, incomplete system and low-efficiency operation eventually resulted in the overall reduction in tariff level. According to investigation for the period from 2002 to 2006, tariff level has witnessed a significant reduction by $10 \%$ on annual basis. Furthermore, such local favorable policies as return of revenue and turnover of reserved spot exchange for bonded areas in conflict with basic principles of WTO have also been canceled gradually.

3.3.2 The Internal Questions of Logistics Park in Bonded Area

Problems within the internal part of bonded areas are stated as follows. Firstly, demand for logistic business in China is so limited, which is unlikely to gain significant economic benefits. Present conditions and prospect of logistics enterprises determine logistics development in bonded areas in the future; whereas significant benefits from logistics development serves as the critical link for the survival and development of logistic enterprises. Underlying cause for unsatisfactory business benefits include inadequate competitive power and business capability of logistics in bonded areas other than reduction in domestic and foreign enterprises' demand for logistics within bonded areas. As pointed out by Li Xuehai, President of Weit Group, one of the biggest logistics warehousing enterprises in U.S.A, inadequate development logistics industry in China has restricted foreign investors from making their way into China's logistic market. People are not clear of the definition of logistics and its values. Furthermore, logistics enterprises in China also have such disadvantages as disordered business items and inadequate expertise. Meanwhile, logistic system in China is in lack of a credit guarantee mechanism. Secondly, professional service level of logistics enterprises requires further improvement. Although administration committee of each bonded area and its affiliates have made great efforts to improve service level, logistics enterprises in bonded area may often neglect this issue. Furthermore, many other problems and outdated logistics service system in bonded area have also seriously affected the international logistics development of bonded area in the future. Therefore, it is essential to improve service level, and make logistic enterprises lay high emphasis on this issue. Thirdly, as many bonded area neglected the establishment of external logistics network system when introducing new logistics enterprises, there is in lack of effective link between the construction of logistics network in bonded areas and external logistics networks. Fourthly, logistics infrastructures in bonded areas are unable to satisfy demands for specialized international logistics.

3.3.3 The Exterior Questions of Logistics Park in Bond Area

External problems with bonded areas: Firstly, Low-efficiency implementation of policies has serious affected functions of good policies in practice to the extent of restricting the development of the park. Secondly, outdated reform of management system, scattered departments and the lack of a clear line between the functions of the government and enterprises have also restricted the development of logistics industry. Thirdly, customs supervision and management system and relevant outdated legal provisions are not in match with the economic development. Meanwhile, legal system is in lack of transparency during implementation. The "taxation before release" entry form has serious affected the clearance efficiency. As a large number of cargoes shall undergo such formalities as declaration, inspection and taxation, it may probably result in the phenomenon of "port bottleneck". Complicated clearance formalities and low-efficiency entry procedures have further affected the work efficiency. Fourthly, bonded areas are not linked up with ports. Support and coordination from port are essential for international logistics development. As most of cargoes in and out of bonded areas are to be handled at ports in China, ports are of vital importance to the development of bonded areas in China. However, bonded area and port are actually two independent departments. Comprehensive benefits from logistics development would be serious restricted if the two departments can not be integrated effectively. 


\section{The Strategy for the Development of Logistics Park in Chinese Bonded Area}

\subsection{Improving International Freeway with Multimodal International Transport System}

Multimodal international transport system refers to the most effective and appropriate comprehensive logistics transport system as formed to satisfy transport demands through flexible application of such features as safety, timelines, large quantity, high speed and comfort of various transport approaches during international transport. In other words, one certain carrier is responsible for integration of numerous transport modes to realize "door-to-door" transport by means of the best services, highest speed and the most competitive price. Such transport mode is favorable for full utilization of transport capacity and effective improvement of overall economic benefits. It is essential for construction of infrastructures and convenient traffic and transport networks as required by international logistics. It can serve as an important "pillar" for international logistics development in bonded areas once conditions for international logistics transport system can be satisfied. Development of multimodal international transport is serves as either orientation for the development of transport industry or quick passage for the logistic enterprises in bonded areas in China to make a transition to international logistics. For instance, multimodal land-sea and sea-railway transport system as centered on Tianjin Port is to be established in Tianjin Free Trade Zone. Shenzhen Free Trade Zone manages to develop multimodal transport system as centered on international transport and sea-railway transport based on its abundant port resources to promote development of other transport modes. In particular, it manages to make use of transport capacity of Beijing-Kowloon Railway, Beijing-Guangzhou Railway and relatively developed highway network in Guangdong Province to realize land-sea link and construction of small land bridge. This aims to promote economic development in mainland while increase the total quantities of transit cargoes.

4.2 Improving the Logistics by Building the International Logistics Information System, by the Information Globalizing

To satisfy operation of modern international logistics, it is essential for bonded areas in China to accelerate the construction of international logistics information exchange system, and ensure communication between bonded areas in China and other foreign countries. This system consists of A: international logistic information, B: international logistics commodity exhibition information, C: international logistics market information, D: international logistics processing information, E: international logistics warehousing information, F: international logistics financial system, G: international logistics dispatching information and $\mathrm{H}$ : international logistics service feedback information on bonded areas.

4.3 Improving the International Logistics Network by Cooperating the Shipping Consortiums

Any international shipping group can act a "pioneer" based on its advanced management system, excellent services, powerful network technologies and intimate cooperative relationship with its clients. This is due to the fact that shipping group has established "door-to-door" multimodal transport network as different from conventional business mode, and commanded $60 \%$ freight agency business of logistic industry all over the world. Thus it can be seen that participation of international shipping group is of vital importance to the construction of bonded areas in China.

4.4 Encouraging the Development of the Third-party and the Forth-party Logistics

Third-party logistics is a transaction mode for logistic service provider to provide series individualized logistics services at the designated price within the specified period of time. Such logistics services are based on the modern IT technologies. Logistics activities and dispatching are executed by logistics companies or warehousing companies. As such companies only provide specialized logistics services other than transaction of commodities, they are deemed as the third party independent of the buyer and seller, namely "third-party logistics". Bonded areas in China have successfully attracted many international enterprises. It is necessary to provide third-party logistics with more opportunities while developing logistics industry in bonded areas. Accenture took the lead in putting forward the conception of fourth-party logistics: Fourth-party logistics provider is an integrator of a supply chain, which aims to integrate and manage different resources, capabilities and technologies of internal departments of a company or a complementary service provider, and provide a complete set of supply chain solutions. Fourth-party logistics has produced 
a complete set of supply chain solution to ensure maximum unification of clients' values ranging from conceptual design and final operation through integration of management information and functions of third-party logistics service providers. Development of fourth-party logistics will further optimize the logistics structures in bonded areas.

4.5 Green Logistics Management in Full Operation

Green logistics is a green economic management process for effective and quick circulation of green commodities and services, which aims to realize customers' satisfaction, link up main green logistics providers and main acquirers, and overcome spatial and temporal obstruction. Green logistics aims to improve logistics system from the environmental angle so as to form an environmental co-existent logistic management system. Integration of logistic management system and "environmental protection" conception is favorable for maintenance of global environment and transformation of conventional linear logistics. A logistics system in ring circulation is designed based on this conception to enable discarded articles on the terminal of conventional logistics to flow back to normal logistics process. Return of discarded articles is known as Reverse Logistics.

4.6 Make More Policy Slope to Encourage the Logistics

First of all, it is necessary to implement principles on market access and free trade within bonded areas, cancel the special permit system to foreign trade, and release foreign trade rights so as to enable industrial and commercial enterprises within bonded area to realize independent import and export. Furthermore, it is necessary to relax approval of joint ventures, and permit foreign investment enterprise in bonded area to establish non-profit resident office outside the bonded areas. It is also necessary to provide favorable policies and operation environment for free exchange of Renminbi within bonded areas. Finally, it is essential to integrate import and export trade with transit trade through promotion of production and circulation so as to realize "release of one line, control of two lines, free operation in bonded areas and promotion of prosperity".

4.7 Improving Customs Clearance System to Adapt the Requirement of International Logistics Development

Firstly, it is necessary to perfect the regulation for making the customs clearance available to control or to prevent runs. Then, it should build a good cooperation relationship between the customs and the enterprises for common development. In the third place, it need optimal the management style. Last but not least, release the most with trust under the stable risk management.

\section{Reference:}

[1] Xianzhang DOU, Qingyang ZHOU; (1998.9) The Certain Direction of Expanding Free-trade Area in Chinese Mainland, Policy Research \& Exploration

[2] Yongshan CHEN; (1988.4) The Free-trade Area in the World, Xiamen University Publisher

[3] Haixiang GAO; (2006.4) The Developing Mode of Chinese Bonded Area, Shanghai Finance and Economics University Publisher 